\title{
モンテカルロ法を用いたドラム式洗濯乾燥機の脱水起動シミュレータ
}

\author{
上甲 康之*1，黒澤 真理*1，高橋 幸太郎*2
}

\section{Dehydration simulator using Monte Carlo approach for front-loading washer-dryer}

\author{
Yasuyuki JOKO ${ }^{* 1}$, Makoto KUROSAWA*1 and Kotaro TAKAHASHI ${ }^{* 2}$ \\ ${ }^{* 1}$ Hitachi, Ltd., Research \& Development Group, Center for Technology Innovation - Mechanical Engineering \\ 832-2 Horiguchi, Hitachinaka-shi, Ibaraki 312-0034, Japan \\ ${ }^{* 2}$ Hitachi Appliances, Inc. \\ 1-1-1 Higashitaga-cho, Hitachi-shi, Ibaraki 316-8502, Japan
}

Received: 28 March 2017; Revised: 30 July 2017; Accepted: 15 November 2017

\begin{abstract}
This paper verifies the validity of the prediction model of clothes behavior by using random number. Outer tub of a frontloading washer-dryer is supported by the vibration isolation structure because the imbalance of clothes inside the drum causes vibration in dehydration. The imbalance beyond an acceptable level is modified by the dehydration control system to reduce the vibration. However, the modification of imbalance causes an extension of operation time. Therefore, it is important to estimate the numbers of modification in initial design stage in order to reduce vibration and operation time. In this study, dehydration simulator was proposed to estimate the numbers of modification using Monte Carlo approach. This simulator consists of three steps; the first step is to generate random numbers following the probability distribution of clothes behaviour obtained by experiment, the second step is to count the random numbers beyond threshold as the numbers of modification, and the third step is to repeat previous steps and to obtain the average number of modification. As a result, the maximum absolute difference of the average number of modification between experiment and prediction was 1.6 times. In addition, the relationship between the threshold and the average number of modification requires about 80 days to be obtained in experiment, but it is shown that the relationship was predicted within a day in proposal method. These results would provide the validity of the proposed approach.
\end{abstract}

Keywords : Vibration control, Probabilistic method, Product design, Washing machine

\section{1. 緒言}

ドラム式洗濯乾燥機は，水を溜める外槽がばねやダンパなどの防振構造によって筐体に支持され，そして外槽 内には回転するドラムが内包されている．脱水時は，ドラムが回転することで，衣類に遠心力が発生し，衣類が ドラム内壁に張り付けられる，そして，ドラムが高速回転することで脱水が行われる．このとき，ドラム内の衣 類の分布に片寄り（以下，アンバランス）がある場合，衣類に作用する遠心力の不釣り合いにより加振力が発生 し，ドラムとそれを内包する外槽とが一体となって振動する。そこで，振動低減のために外槽と筐体との間には ばねやダンパなどの防振構造が設けられている.

また, ドラム式洗濯乾燥機には, 脱水時の振動低減のために脱水起動制御が搭載されている. 脱水起動制御は, 検出したアンバランス量あるいは外槽振動などの振動レベルが予め決めた閾值以上と判定された場合に，一旦ド ラムの回転を減速あるいは停止し，脱水のやり直し（以下，リトライ）を行うことでアンバランスの修正を行う. このリトライは，検出した振動レベルが閾值よりも小さくなるまで繰り返されるため，最終的にはアンバランス が小さくなり低振動化・低騒音化を図ることが出来る。しかしながら，このリトライが何度も行われると，脱水 時間の延長をもたらす. したがって, 脱水起動制御には振動低減とリトライ回数低減の両立が求められる.

No.17-00140 [DOI:10.1299/transjsme.17-00140], J-STAGE Advance Publication date : 28 November, 2017

${ }^{*}$ 正員, (株) 日立製作所 研究開発グループ 機械イノベーションセンタ（テ312-0034 茨城県ひたちなか市堀口 832-2)

*2 日立アプライアンス（株）＼cjkstart家電事業部（†316-8502 茨城県日立市東多賀町 1-1-1）

E-mail of corresponding author: yasuyuki.joko.qd@hitachi.com 
一方, 過去の研究では, 防振構造の最適化が中心に行われており, 脱水起動制御は考慮されていない. 防振構 造の最適化は，ばね定数や支持位置などを設計変数とする組合せ問題であり, 設計変数の増加に伴い検討する組 合せ数が急激に増加する. そこで, 効率的に最適化を行う方法として, 振動解析モデルを用いる方法 (紀之内他, 2000）や，実験計画法（辻内他，2006），タグチメソッド（松井他，2008），応答曲面（上甲他，2016）などを用 いる方法が提案されている. これらは防振構造の最適化によって, アンバランス量に対する外槽の振動応答を最 小化するものである. しかしながら，これらは脱水起動制御を考慮していないため, リトライ回数の評価は実機 で行う必要がある，その結果，リトライ回数の評価は実機が完成する設計後期に行われることになり，この段階 でリトライ回数が基準を超過していたとしても, 防振構造の変更の自由度が小さく, 改良が難しくなる. したが って, 脱水起動制御を考慮した防振構造設計を行うためには, 防振構造の設計初期段階でリトライ回数を予測す ることが求められる.

そこで本研究では，実機の無い設計初期段階でリトライ回数を評価するために，モンテカルロ法を用いた脱水 起動シミュレータの開発を行った. リトライ回数を評価するためには, 複雑な衣類挙動を再現する必要がある.

脱水起動シミュレータでは, 衣類の挙動により外槽の振動レベルがある確率分布となることに着目し, その確率 分布に従う乱数を発生させて闇值と比較することで, リトライ回数を予測するものである. 本報では, ドラムの 直径 $D$ と奥行き長さ $L$ の異なる 2 種類のドラム式洗濯乾燥機について, 実際の脱水動作で得られたリトライ回数 の実験值と予測值との比較を行い, 本予測方法の有用性を検証した.

\section{2. ドラム式洗濯乾燥機の構造と制御}

\section{$2 \cdot 1$ 防振支持構造}

図 1 は, ドラム式洗濯乾燥機の防振構造を示寸模式図であり, 図 1(a)に正面図, 図 1(b)に右側面図を示す. 衣 類を収納するドラムは，前端面の開口部に流体バランサを備え，水を溜める外槽に内包されている．またドラム は, 外槽の背面にあるモータによって, 回転駆動が可能である. ドラムの中には, 衣類を攪拌するためのリフタ が設けられている，外槽は，上部のばねと，両端にゴム製のブッシュを備えるサスペンションとによって，外郭 を成す筐体に 6 自由度で弾性支持されている. 外槽の開口部は, ゴム製の蛇腹によって筐体と接続され, 水封さ れている. また外槽には, 外槽の振動を検出するための加速度センサが設けられている. なお, 本研究では, ド ラム容積がほぼ同等で，ドラムの直径 $D$ と奥行き長さ $L$ が異なる 2 種類について検討を行ったため, ドラムア スペクト比 $\alpha=D / L$ で 2 種類を区別した.

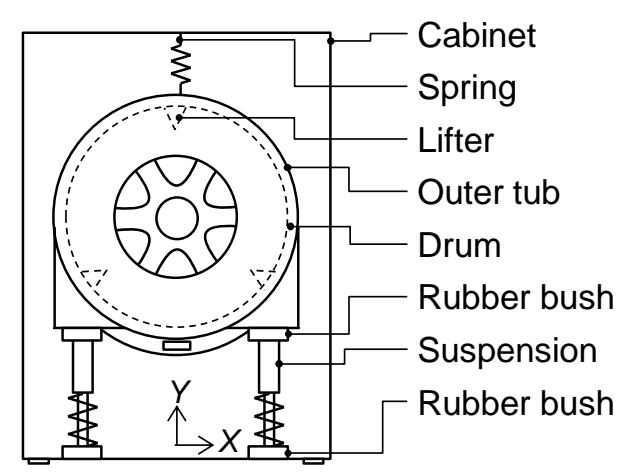

(a) Front view

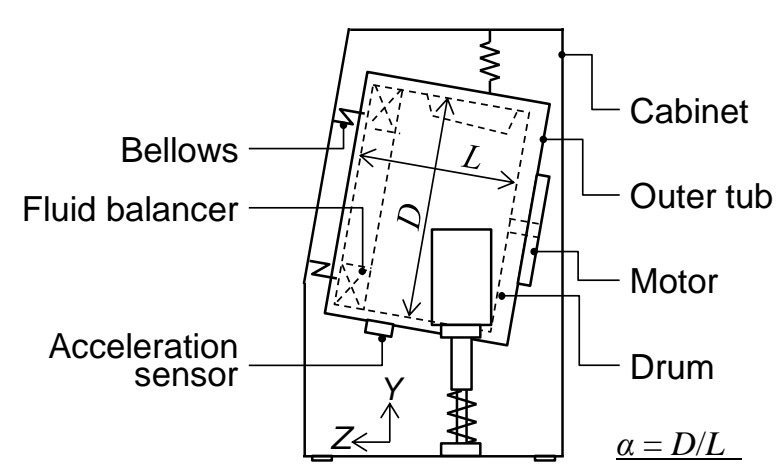

(b) Right view

Fig. 1 Vibration isolation structure of front-loading washer-dryer

\section{$2 \cdot 2$ 脱水起動制御}

ドラム式洗濯乾燥機では，運転中に脱水起動が複数回行われる．脱水起動とは，図 2 に示寸運転行程の内, 「す寸ぎ行程（Rinsing proc.)」と「脱水行程（Dehydration proc.)」で行う脱水動作（Spin）で，ドラムが停止状 態から定常回転に至るまでの立ち上がりのことである. 脱水起動では，ドラム回転数の上昇中にいくつかの共振 回転数を通過し, 外槽や筐体の振動が極大となる時に, アンバランスによっては異音を発生させる場合がある. 
そのため, 予め許容できる振動レベルを決定し, 加速度センサやモータなどの振動検出手段から得た出力から, その振動レベルを超えたと判定した場合に，ドラムの回転を減速あるいは停止させて，リトライする脱水起動制 御が搭載されている.

脱水起動制御は，図 3 に示すように，(A)衣類の張り付け区間，(B)共振通過区間，(C)定常回転区間の 3 つの 動作に分けられる。(A)衣類の張り付け区間では，まずドラムを回転させて衣類の絡みを解消するほぐし動作を 行う。次に，ドラムを一方向に回転させて，リフタで衣類の攪拌を行いながら，遠心力でドラム内壁に衣類を張 り付ける動作を行う。このとき，ドラム内壁に張り付いた衣類の質量分布が均一ではない場合にアンバランスが 発生する. そこで, 振動検出手段で検出した振動レベルと, 予め決めた閾值とを比較し, 振動レベルが閾值より も小さければ次の(B)共振通過区間へ移行する. (B)共振通過区間では，ドラムの回転上昇に伴い，複数の共振回 転数を通過して外槽と筐体の振動が極大となるため，検出した振動レベルと閾值とを常に比較しながら，目標回 転数に向けて回転上昇を行う。目標回転数に到達後は，(C)定常回転区間で一定回転数のまま所定の時間脱水を 行い，その後ドラムを減速・停止させて脱水起動は終了する.

$\overbrace{\text { Wash }>\text { Spin 1 }>\text { Rinse 1 }}^{\text {Washing proc. }} \overbrace{\text { Spin 2 }}^{\text {Rinsing proc. }} \overbrace{\text { Rinse 2 }}^{\text {Rinsing proc. }}$ Dehydration proc. $\overbrace{\text { Spin 3 }}^{\text {Drying proc. }}$

Fig. 2 Operation process of washer-dryer

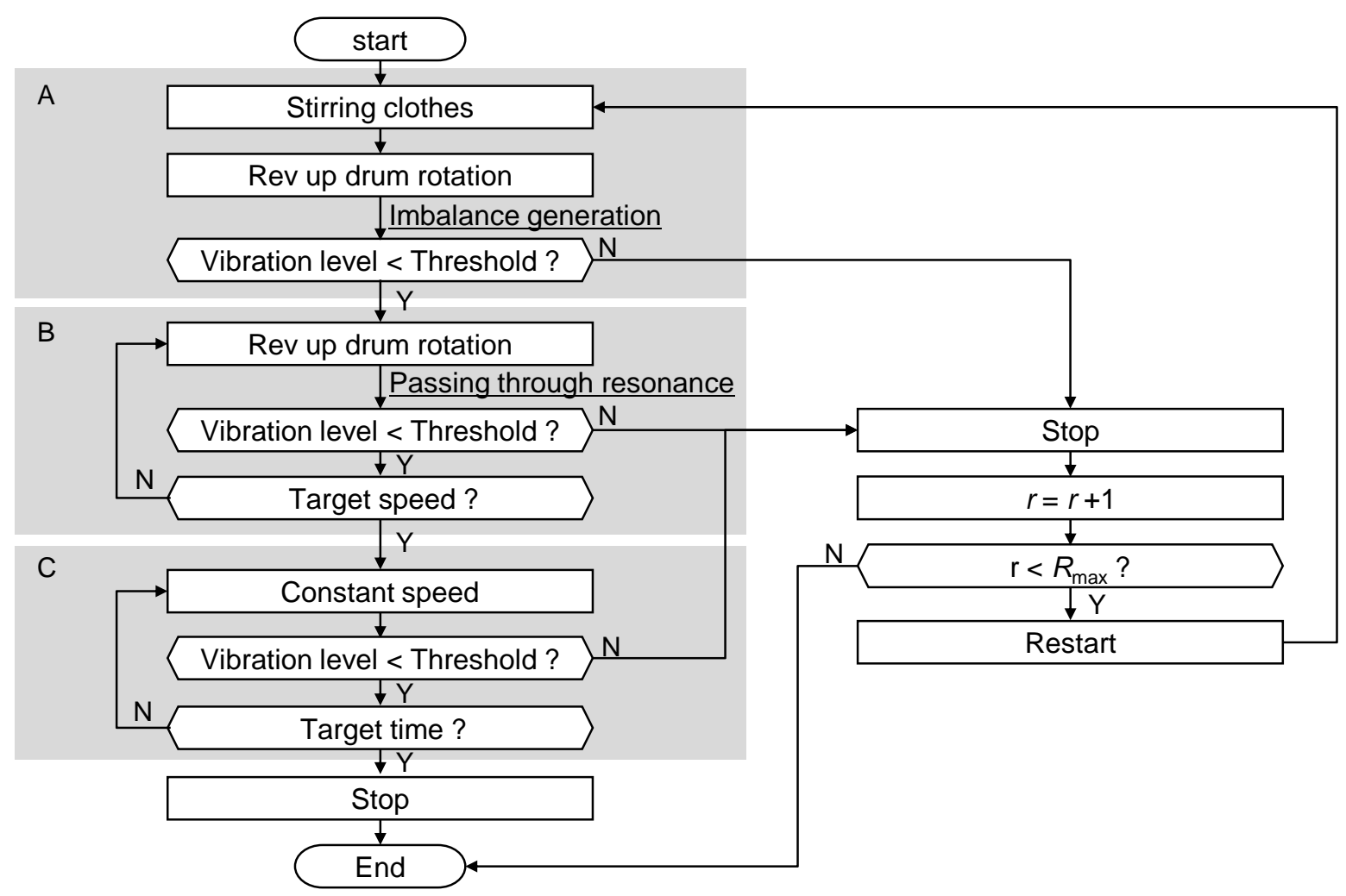

Fig. 3 Control flow diagram of dehydration 
ここで，検出した振動レベルが閾值以上の場合，リトライによるアンバランスの修正を行うことで過大な振動 や騒音の発生を防いでいる。 リトライは，一旦ドラムの回転を停止，あるいは衣類がドラム内壁から重力で剥が れおちるまで減速させ，再び(A)衣類張り付け区間に移行するものである. またリトライは，検出した振動レべ ルが閾值以下となるまで繰り返されるが，その回数（リトライ回数） $r$ が上限 $R_{\max }$ 以上になった場合は, アンバ ランスの修正は出来ないと判定して, 脱水起動を終了し次の工程へ移行する.

\section{3. 脱水起動シミュレータ}

本研究では，設計初期段階でリトライ回数を予測するために，脱水起動シミュレータの開発を行った．なお， 本報告では，衣類から水が抜ける影響の小さい図3(A)衣類張り付け区間でリトライした場合を対象とした.

\section{$3 \cdot 1$ リトライ回数の算出方法}

脱水起動シミュレータでは, 衣類の挙動で変化する外槽の振動レベルの確率分布に着目し（後述の図 7 参 照), 乱数を用いてそれを再現した（モンテカルロ法）。本研究における外槽の振動レベルとは, 図 3 の(A)衣類 張り付け区間における閾值との比較で用いた検出量である.ここで, 図 4 に衣類の挙動により発生する外槽の振 動レベルの概念図を示寸．図4(a)より，リトライによるアンバランス修正前（以下，バランス前）において，無 次元化された振動レベルが平均值 $\bar{x}$ の確率分布 $f_{1}(x)$ になると仮定すると, 闇值 $S_{x}$ より右側の斜線部分は全てリ トライになる. そして，リトライを複数回繰り返した後（以下，バランス後）の振動レベルは，最終的に図 4(b) のような平均值 $\bar{X}$ の確率分布 $f_{2}(x)$ になる. 寸なわち, 確率分布 $f_{1}(x)$ となる乱数を発生させて, その乱数 $x$ が閾 值 $S_{x}$ 以上であれば亲却し, 閾值よりも小さければ受理することを繰り返した時の, 乱数 $x$ の棄却回数を求める ことで, リトライ回数が算出可能と考えた.

このような統計的方法をとった理由は，衣類は互いに絡み合うことで挙動が極めて複雑となり，物理的または パラメトリックな定式化が困難であることが挙げられる. また, リトライによりアンバランスの修正を図るが, 必ずしも成功するわけではなく, 物理的な要素よりも確率的な要素の方が大きいことも理由の一つである.

ここで, 脱水起動シミュレータのアルゴリズムを図 5 に示す. まず繰り返し回数, すなわち乱数のサンプル数 $N$ と, リトライ回数の上限 $R_{\max }$ を与える. 今回は, サンプル数 $N$ を $10000, R_{\max }$ を 20 とした. そして, ステッ プ $i(=1,2, \cdots, N)$ で, 目標の確率分布 $g(x)$ に従うような乱数を 1 つ発生させて $x$ を取得する. この目標の確率 分布 $g(x)$ は, 予め実験で求めた振動レベルの確率分布であり, 実際の衣類の挙動に相当する. 乱数 $x$ が閾值 $S_{x}$ 未 満であれば, その乱数 $x$ をバランス後の振動レベル $X_{i}$ とし, カウンタ $r$ をリトライ回数 $R_{i}$ とする. 一方, 乱数 $x$ が閾值 $S_{x}$ 以上であれば，リトライ回数のカウンタ $r$ を更新する. このとき，リトライ回数のカウンタ $r$ がリトラ イ回数の上限 $R_{\max }$ よりも大きければ, その時点のカウンタ $r$ をリトライ回数 $R_{i}$ とし, カウンタ $r$ がリトライ回 数の上限 $R_{\max }$ 以下であれば再び確率分布 $g(x)$ に従うように乱数 $x$ を発生させる. このステップ $i$ をサンプル数 $N$ の 10000 回繰り返すことで, バランス前の振動レベルに相当する確率分布 $f_{1}(x)$, バランス後の振動レベルに相当 する確率分布 $f_{2}(x)$, バランス後の振動レベル $\bar{X}$, そして平均リトライ回数 $\bar{R}$ が評価值として得られる.

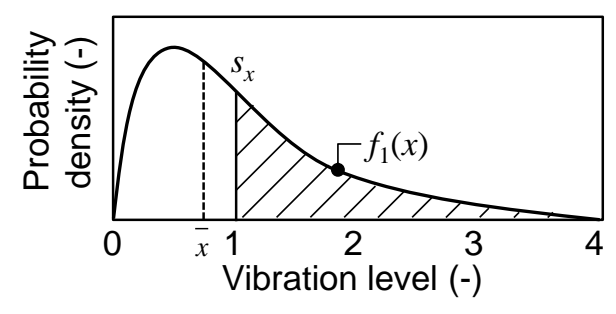

(a) Before balancing

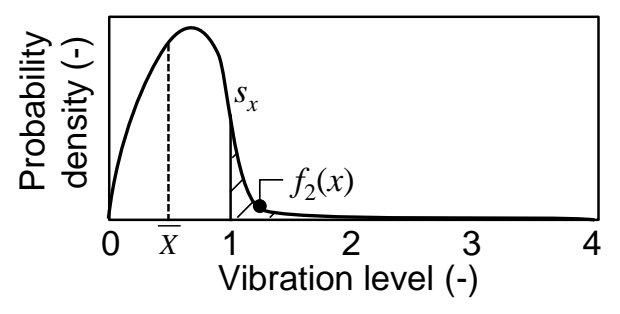

(b) After balancing

Fig. 4 Concept diagram of vibration level generated by clothes behavior 


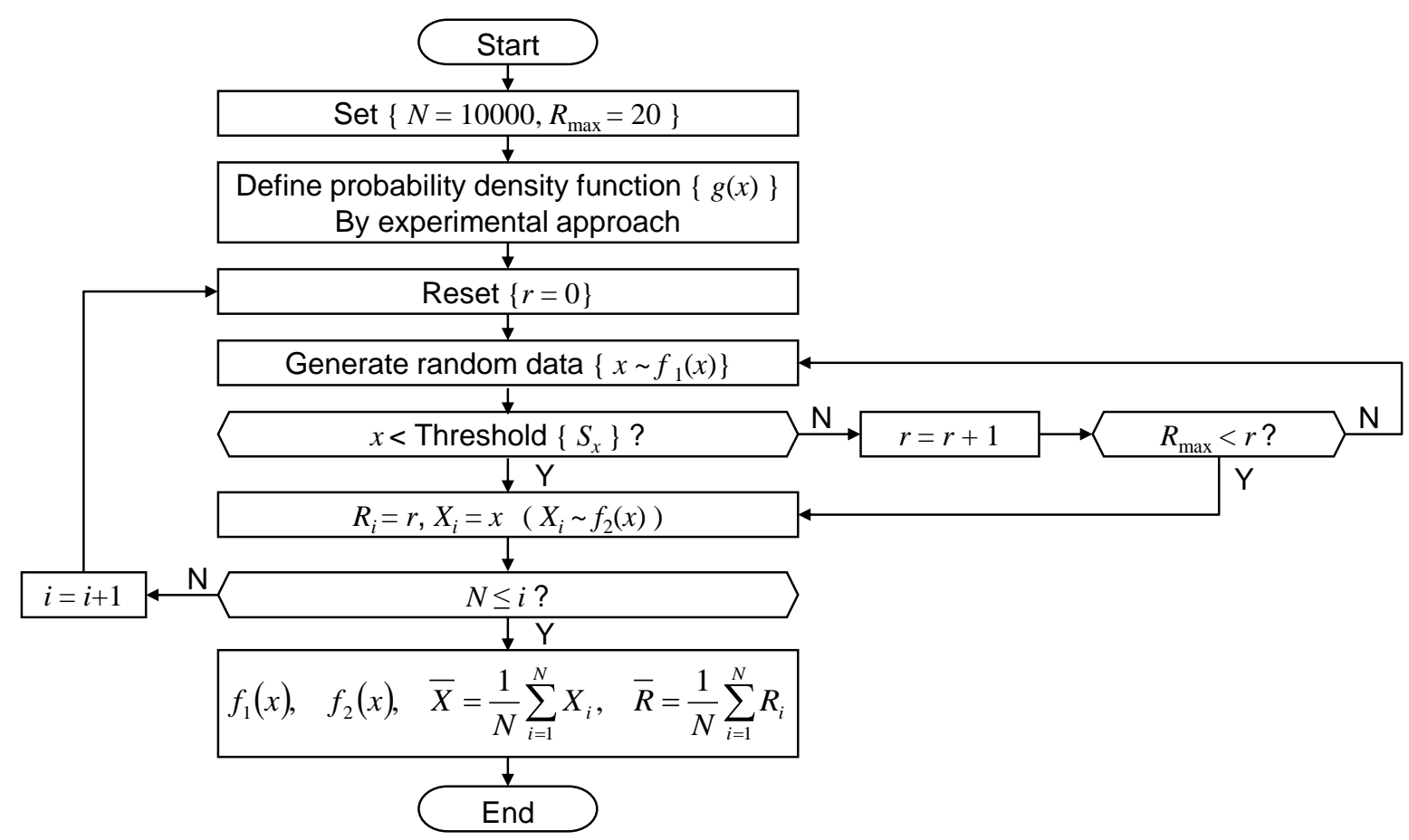

Fig. 5 Algorithm of a proposed simulator for dehydration control system

\section{$3 \cdot 2$ 乱数の発生方法}

脱水起動シミュレータは, 乱数で得た振動レベルの確率分布 $f_{1}(x)$ が, 実際の衣類挙動に相当する振動レベルの 確率分布 $g(x)$ を再現していることが前提となる. ここで, 目標となる確率分布 $g(x)$ に従う乱数を発生させる方法 として, 確率分布 $g(x)$ を正規分布やポアソン分布のような数式で記述される確率分布で定義する方法もあるが, 衣類の挙動に適した確率分布が無かったため, 今回は実験で得た確率分布 $g(x)$ に従う乱数を発生させる方法とし た．その方法は，まず図 6(a)に示すように，ヒストグラムで表される実験データを連続関数で補間した目標確率 分布 $g(x)$ を考える. 次に, 確率密度 1.0 の一様分布 $u(x)$ と目標確率分布の頂点 $M$ の積 $M \times u(x)$ を生成し, 斜線部 を较却する. そして棄却されずに残った乱数から得た確率分布 $f_{1}(x)$ が得られる. その結果, 図 6(b)のように, 実 験データと一致するような乱数を発生させることが出来る. この方法は, 乱数の発生に一様分布を用いること で, 目標の確率分布 $g(x)$ がどのような形状になっても乱数で再現可能と考えられる.

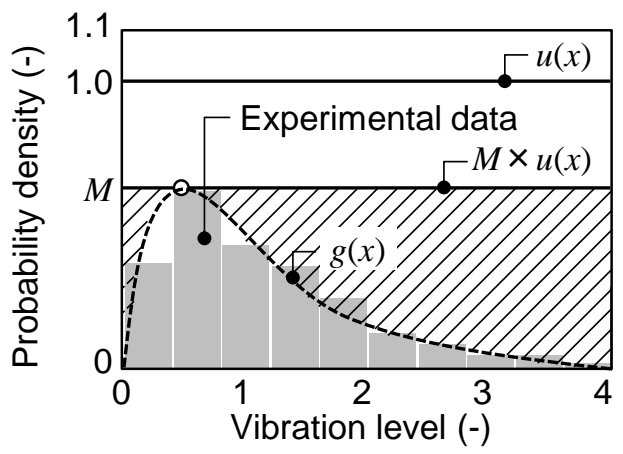

(a) Probability density $g(x)$ obtained by experimental data

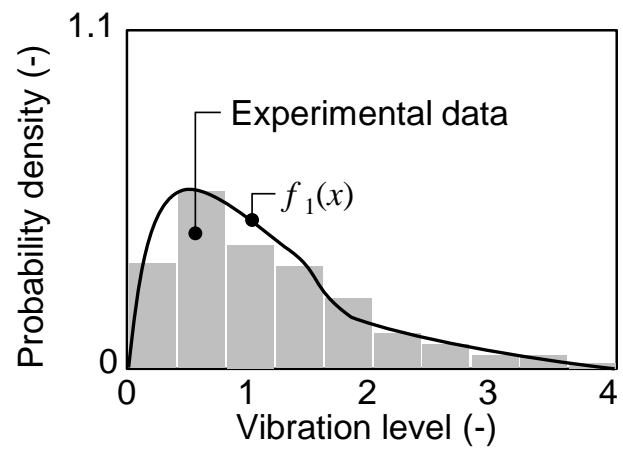

(b) Probability density $f_{1}(x)$ obtained by random data

Fig. 6 Method for Generating distribution of vibration level 
ここで，これら確率分布 $g(x)$ と $f_{1}(x)$ の補間には，ガウシアンカーネル密度推定を用いた．ヒストグラムが階級 幅に入るデータの数 (頻度) をブロックのように積み重ねて描かれるのに対して, ガウシアンカーネル密度推定 は，各データを中心とする分布であるカーネル関数を積み重ねるものである．これによれば，図 6 のように，確 率分布は階級幅に依存しない滑らかな曲線となるため, 異なる確率分布同士の比較が行いやすくなる他, 数式で 表現できるためシミュレーションに利用し易いという特徵がある.

ここで, サンプル数 $n$ のデータ $z_{1}, z_{2}, \ldots, z_{i}$ を独立で同一なガウス分布に従うと仮定したとき，各データを 中心とするガウス分布のカーネル密度関数 $K(z)$ は,

$$
K(z)=\frac{1}{\sqrt{2 \pi}} e^{\frac{-z^{2}}{2}}
$$

で表される. 式(1)のカーネル密度関数 $K(z)$ を積み重ねると, 変数 $x$ のカーネル密度推定 $f_{K}(x)$ は,

$$
f_{K}(x)=\frac{1}{n h} \sum_{i=1}^{n} K\left(\frac{x-z_{i}}{h}\right)
$$

となる，なお， $h$ はバンド幅（積み重衫る分布の幅）であり，標準偏差 $\sigma$ を用いて式(3)とした。これは，ノーマ ル・リファレンス・ルールと呼ばれるもっとも基本的なバンド幅である.

$$
h=\frac{1.06 \sigma}{n^{\frac{1}{5}}}
$$

\section{$3 \cdot 3$ 発生させた乱数の妥当性検証}

リトライ回数を算出する前に，発生させる乱数が実際の衣類挙動を再現しているかを検証した．まずは，実際 の衣類を用いて脱水起動時の振動レベルを次の 3 ステップで測定した. ステップ 1 では, 所定の質量となるよう に，任意の種類で組み合わされた衣類を 1 枚ずつ無作為にドラム内に投入する. ステップ 2 では, 専用の制御ソ フトを用いて，図 2 の洗い行程を行った後に図 3 の(A)衣類張り付け区間を 15 回繰り返す，ステップ 3 では，運 転を終了してドラムから衣類を取り出す．これにより得られる振動レベルのデータは，運転当たり 15 個で，さ らにステップ 1〜3 を5 サイクル繰り返すことで, 合計 75 個となる.この 75 個のデータから目標となる確率分 布 $g(x)$ を作成し，それを再現する確率分布 $f_{1}(x)$ を求めた.

ここで図 7 は，布量とドラムの種類を変化させて，実験で得た振動レベルのヒストグラムと乱数から得た確率 分布 $f_{1}(x)$ を比較した結果である. 図 7 の横軸は，閾值 $S_{x}$ を 1 として無次元化した振動レベルである. 図 7 よ り, 実験と計算の $f_{1}(x)$ で共に, 布量 $7 \mathrm{~kg}$ 以下では得られた振動レベルが広く分布しているのに対して, 布量 $11 \mathrm{~kg}$ の実験で得られた振動レベルは狭い範囲に分布した。これは，ドラムの容積に対して衣類の占める割合が 大きく, ドラムの回転で衣類が動きにくい為と考えられる. 寸なわち，布量 $11 \mathrm{~kg}$ の場合はドラムに投入した際 の初期状態の影響が大きく，その後の運転行程で同じような振動レベルが発生し易い. このような釣鐘形状では ない分布形状に対しても，乱数で得た確率分布 $f_{1}(x)$ も同様の形状となっている. このことから，バランス前の振 動レベルとして，今回求めた乱数は妥当であると考えられる.

なお，本研究ではシミュレータの妥当性検証を目的に，詳細な製品化実証試験のうち，代表的な条件で実験を 行った. このように条件を抽出する場合でも, 脱水工程からスタートして振動レベルを測定するのではなく, 事 前に洗い工程を実施する方が望ましい。これは, 洗い工程における衣類の絡み具合が, 脱水時の衣類挙動に大き く影響するためである. 


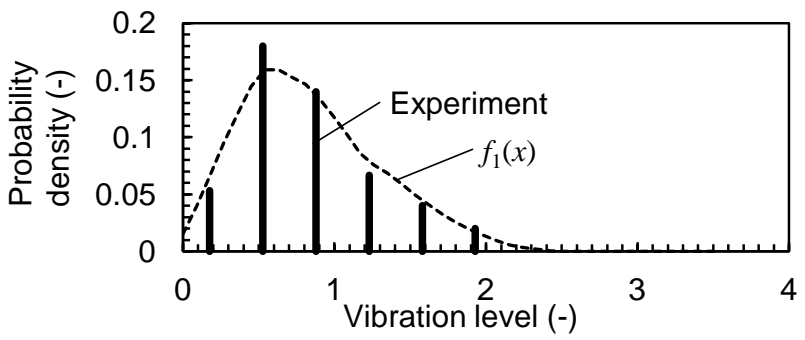

(a) Mixed clothes $1 \mathrm{~kg}$ ( Drum aspect ratio $\alpha=2.0$ )

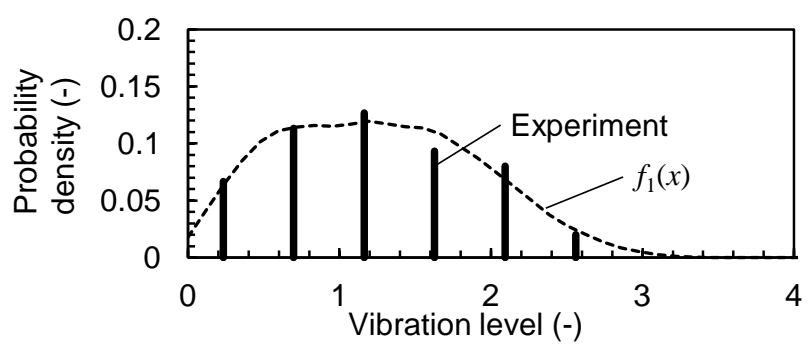

(c) Mixed clothes $3 \mathrm{~kg}$ ( Drum aspect ratio $\alpha=2.0$ )

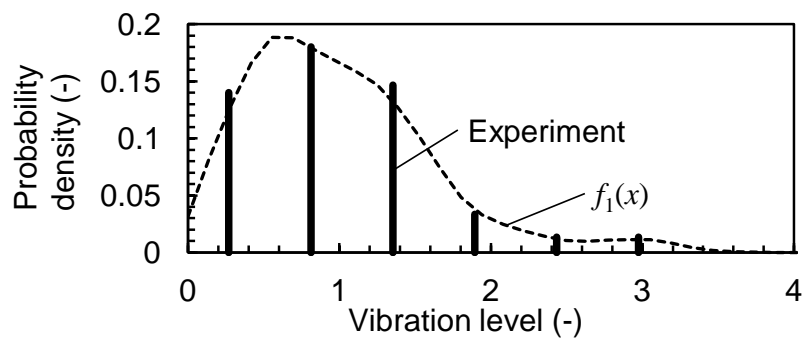

(e) Mixed clothes $5 \mathrm{~kg}$ ( Drum aspect ratio $\alpha=2.0$ )

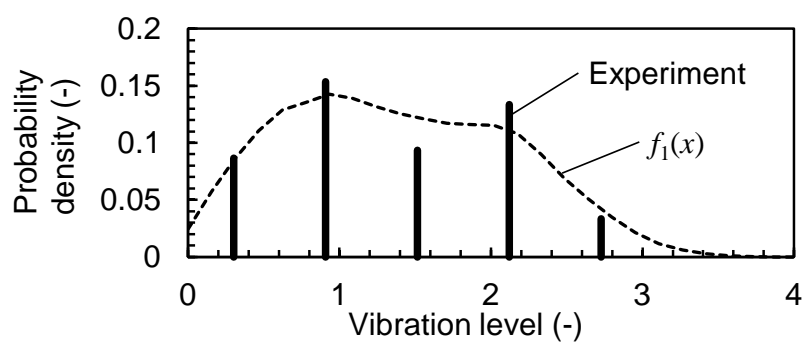

(g) Mixed clothes $7 \mathrm{~kg}$ ( Drum aspect ratio $\alpha=2.0$ )

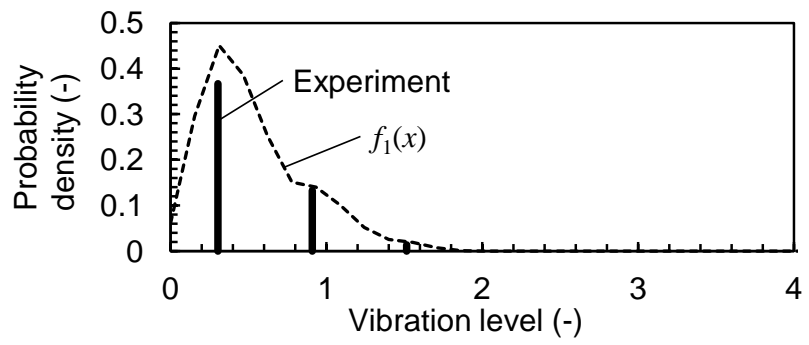

(i) Mixed clothes $11 \mathrm{~kg}$ ( Drum aspect ratio $\alpha=2.0$ )

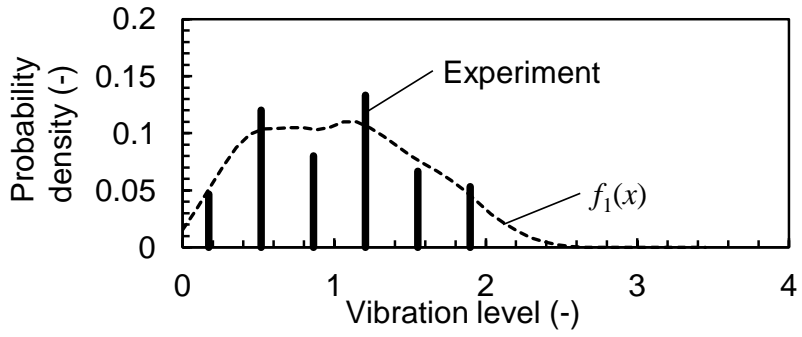

(b) Mixed clothes $1 \mathrm{~kg}$ ( Drum aspect ratio $\alpha=1.3$ )

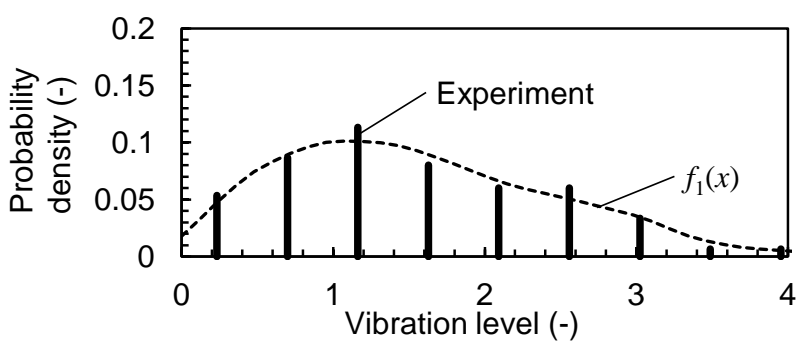

(d) Mixed clothes $3 \mathrm{~kg}$ ( Drum aspect ratio $\alpha=1.3$ )

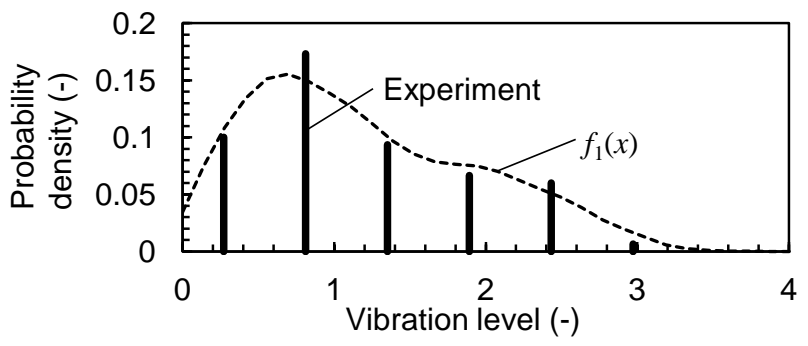

(f) Mixed clothes $5 \mathrm{~kg}$ ( Drum aspect ratio $\alpha=1.3$ )

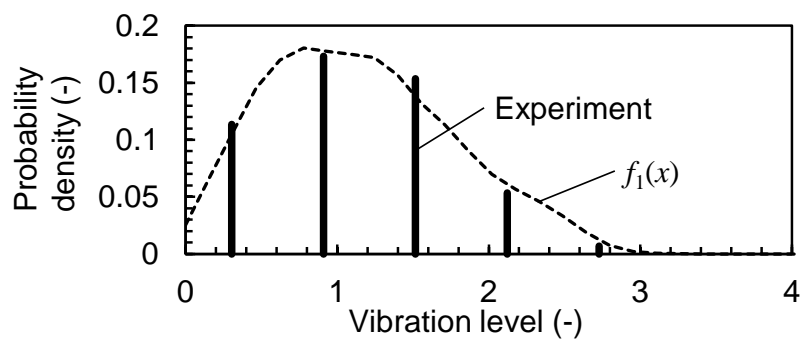

(h) Mixed clothes $7 \mathrm{~kg}$ ( Drum aspect ratio $\alpha=1.3$ )

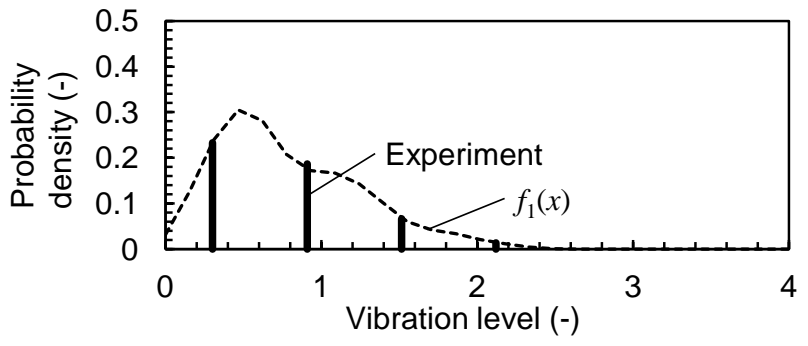

(j) Mixed clothes $11 \mathrm{~kg}$ ( Drum aspect ratio $\alpha=1.3$ )

Fig. 7 Comparison of non-dimensional vibration level before balancing between experiment and $f_{1}(x)$

( Threshold of vibration level $=1.0$ ) 


\section{4. 結果と考察}

\section{$4 \cdot 1$ 検証方法}

脱水起動シミュレーションの有用性を検証するために, 布量とドラムの種類を変化させて, 表 1 に示す条件で 脱水起動実験の結果との比較を行った. 脱水起動実験は, 3.3 節と同様に, 運転ごとに衣類を 1 枚ずつ無作為に投 入し，3 回の脱水動作が行われるように設定した洗濯運転（図 2 参照）を 5 回行った. 一方, 脱水起動シミュレ 一タに与える条件は, 前節で求めたバランス前の振動レベル $f_{1}(x)$ と, 衣類量ごとに決められた振動レベルの閾值 である. 以上の条件で, 脱水動作ごとに得られるリトライ回数を平均化した平均リトライ回数の比較を行う.

Table 1 Experimental Conditions

\begin{tabular}{cc}
\hline Experimental model & $\alpha=2.0, \alpha=1.3$ \\
\hline Number of dehydration & 3 times $/$ cycle \\
Repeating experiments & 5 cycle \\
Clothes & $1 \mathrm{~kg}, 3 \mathrm{~kg}, 5 \mathrm{~kg}, 7 \mathrm{~kg}, 11 \mathrm{~kg}$ \\
\hline
\end{tabular}

\section{$4 \cdot 2$ 検証結果}

図 8 は, 脱水起動実験で得られた平均リトライ回数から脱水起動シミュレータで得られた平均リトライ回数 $\bar{R}$ を引いた絶対差である. 図 8 より, 実験と予測の差は, ドラムアスペクト比 $\alpha=1.3$ の機体で最大 1.6 回となった が， $\alpha=2.0$ の機体では最大 0.8 回となり, 良好に一致した. ドラムアスペクト比 $\alpha=1.3$ の機体は, 衣類量が $3 \sim$ $11 \mathrm{~kg}$ で実験と予測の差が $\alpha=2.0$ の機体よりも大きいが，約 1.0 でほぼ一定となっていることから，布量に対する 増減傾向は概ね一致していると考えられる. なお，ドラムアスペクト比 $\alpha=1.3$ の機体で計算よりも実験の平均リ トライ回数が大きいのは, ドラム奥行き寸法 $L$ が長い分, 衣類が前後に動きやすく, 図 9 より脱水起動実験の標 準偏差が大きいことから，実験のばらつきが原因の 1 つと考えられる.

ここで図 10 は, 閾值 $S_{x}$ 以下となるまでリトライを繰り返した後の振動レベルの確率分布 $f_{2}(x)$ を比較したもの である. 図 10 には，実験と予測で得られた振動レベルの平均值 $\bar{X}$ をれぞれ括弧で付してあり，実験に対する その相対誤差を Error で示してある. 図 10 より, 振動レベルの平均值 $\bar{X} の$ 相対誤差は, 布量全体で平均すると, ドラムアスペクト比 $\alpha=1.3$ の機体で $13.9 \%, \alpha=2.0$ の機体で $6.2 \%$ となった．前節で求めた振動レベルが広く分 布しているほど誤差が大きい傾向にあるが，実験と予測は共に閾值 1.0 付近でほぼゼロとなっており，傾向は図 4 で示した考え方と一致する. このことは, 図 7 に示すバランス前の振動レベルから, バランス後の振動レベル の予測が可能であることを示している.すなわち, 閾值による振動レベルの低減量を見積もることが出来るため, 防振構造設計と共に闇值の検討も可能となる.

以上より，開発した脱水起動シミュレータは，平均リトライ回数の予測とバランス後の振動レベルの予測が出 来る見込みを得たことから，脱水起動制御を考慮した防振構造設計が可能となるため，その有用性は高いと考え られる。

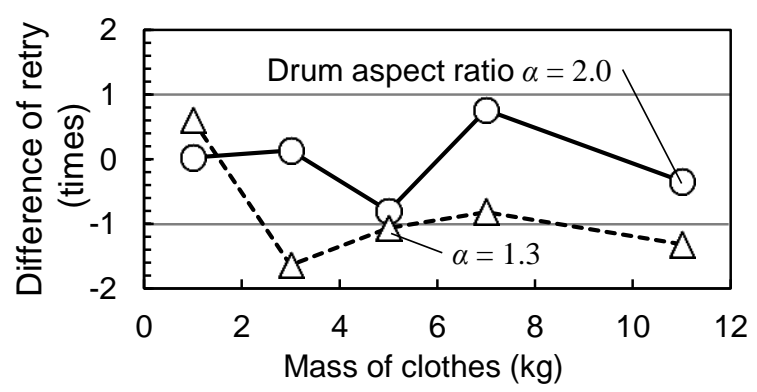

Fig. 8 Comparison of the average number of retry between experiment and prediction

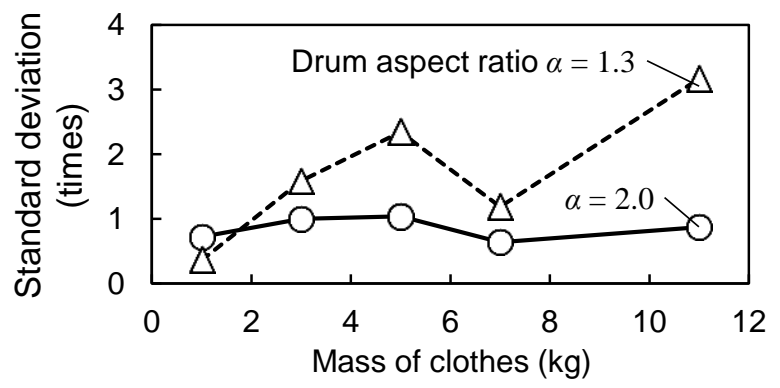

Fig. 9 Standard deviation of the number of retry in experiment 


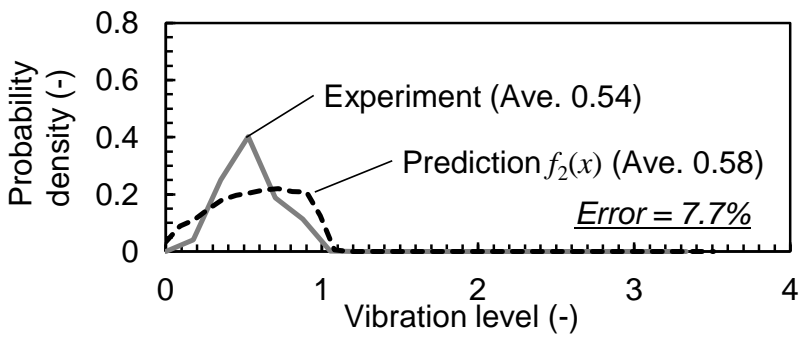

(a) Mixed clothes $1 \mathrm{~kg}$ ( Drum aspect ratio $\alpha=2.0$ )

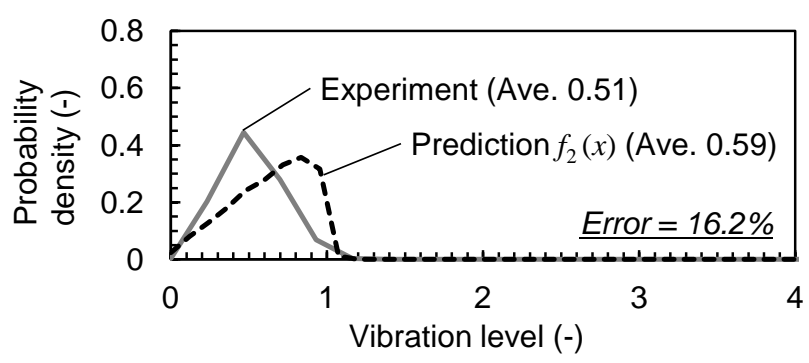

(c) Mixed clothes $3 \mathrm{~kg}$ ( Drum aspect ratio $\alpha=2.0$ )

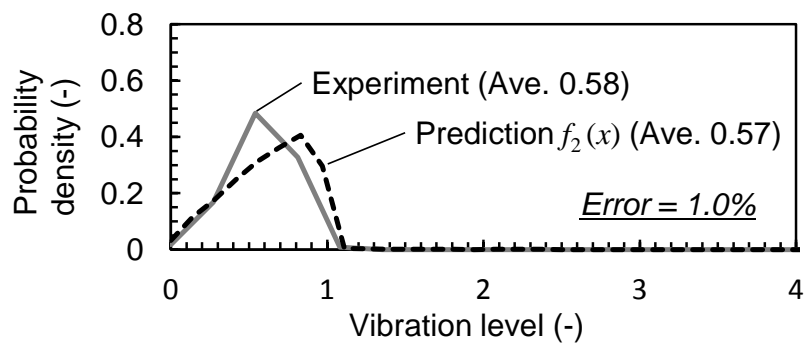

(e) Mixed clothes $5 \mathrm{~kg}$ ( Drum aspect ratio $\alpha=2.0$ )

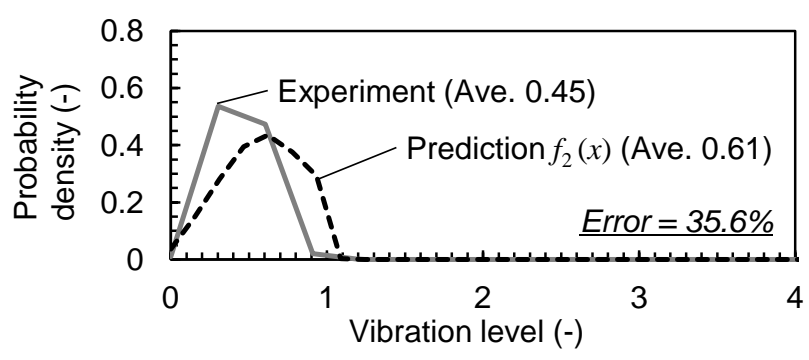

(g) Mixed clothes $7 \mathrm{~kg}$ ( Drum aspect ratio $\alpha=2.0$ )

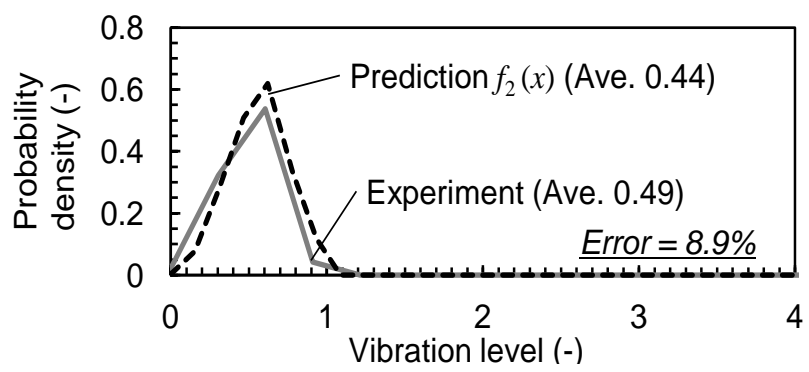

(i) Mixed clothes $11 \mathrm{~kg}$ ( Drum aspect ratio $\alpha=2.0$ )

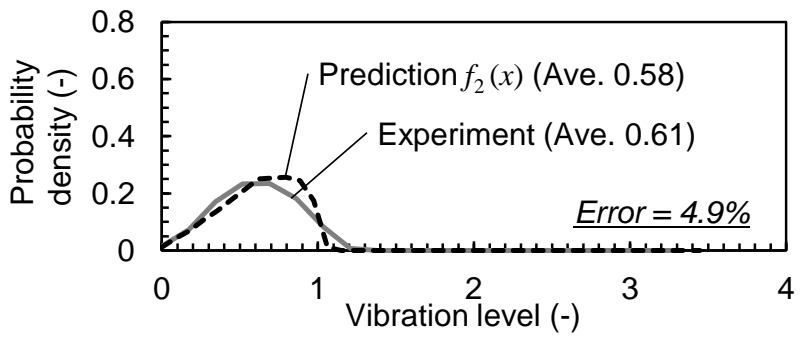

(b) Mixed clothes $1 \mathrm{~kg}$ ( Drum aspect ratio $\alpha=1.3$ )

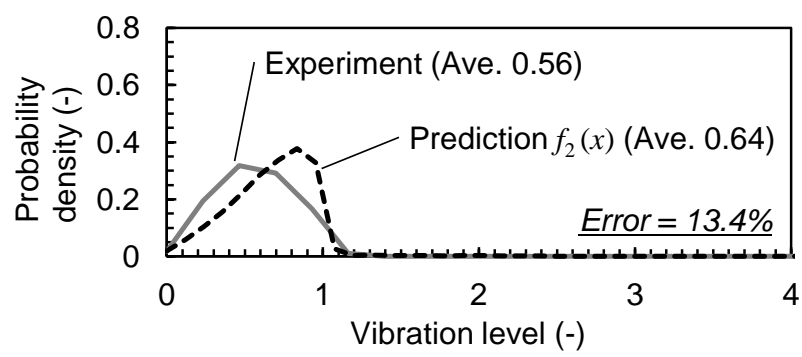

(d) Mixed clothes $3 \mathrm{~kg}$ ( Drum aspect ratio $\alpha=1.3$ )

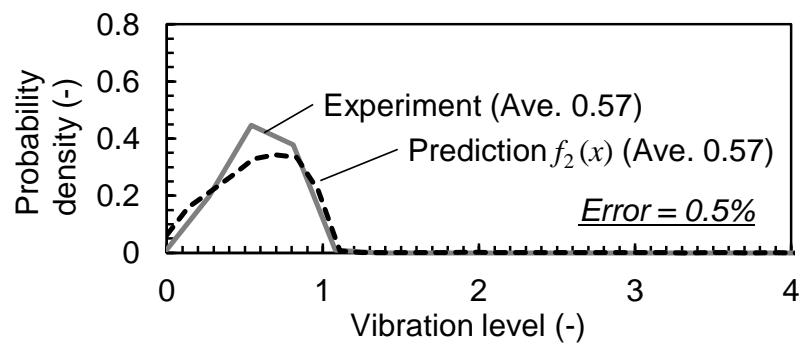

(f) Mixed clothes $5 \mathrm{~kg}$ ( Drum aspect ratio $\alpha=1.3$ )

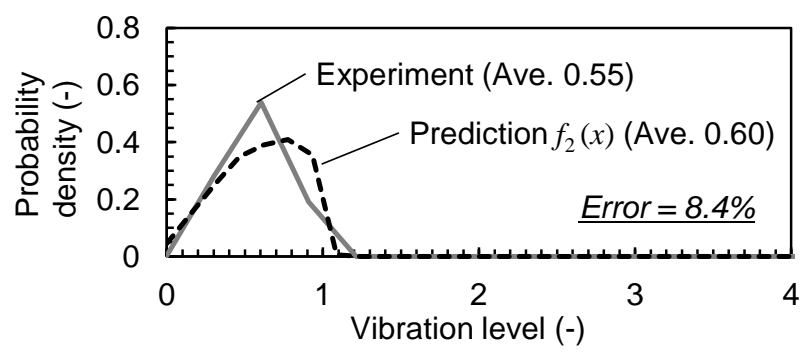

(h) Mixed clothes $7 \mathrm{~kg}$ ( Drum aspect ratio $\alpha=1.3$ )

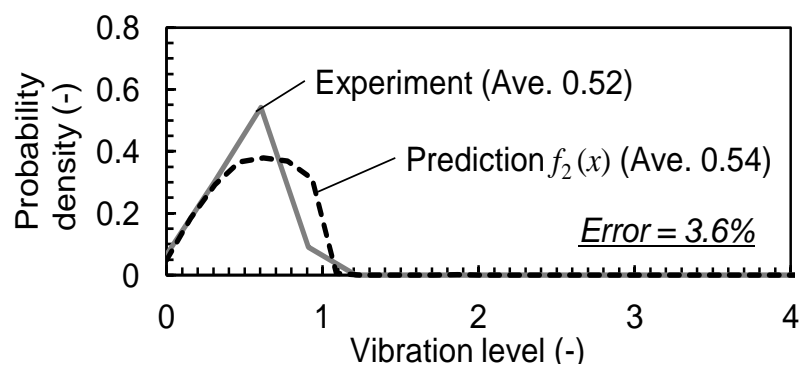

(j) Mixed clothes $11 \mathrm{~kg}$ ( Drum aspect ratio $\alpha=1.3$ )

Fig. 10 Comparison of non-dimensional vibration level after balancing between experiment and prediction ( Threshold of vibration level $=1.0$ ) 


\section{$4 \cdot 3$ 脱水起動シミュレータの応用}

開発した脱水起動シミュレータは，実験では膨大な時間を要するため求めることが困難な関係も短時間で予測 することができる. ここで，前節で用いた閾值 $S_{x}$ に対する比の無次元閾值と，前節の計算で得た平均リトライ 回数に対する比の無次元平均リトライ回数の関係を図 11 に示す. 例えば，前節で用いた閾値 $S_{x}$ よりも10\%小さ い無次元闇值 0.9 のとき, 平均リトライ回数が前節の計算結果よりも増加することを示している. これは, 本研 究の対象機で振動レベルが無次元閾值で 1.0 となるアンバランス量を定義すると，そのアンバランス量よりも $10 \%$ 小さいときに平均リトライ回数が増加する関係と同等である. 寸なわち, 図 11 は, 本研究の対象機で許容 可能なアンバランス量と平均リトライ回数に対して, 防振構造の変更で許容可能なアンバランス量が変化した時 の, 平均リトライ回数の変化率の関係を表している. なお，一般機に適用する場合は，まず振動レベルが一般機 固有の現状の閾值となるアンバランス量を定義し，それに対する許容可能なアンバランス量の変化率を無次元閾 值として考えれば良い.

ここで, 図 11 のような無次元闇值と無次元平均リトライ回数の関係を描くためには, 評価点ごとに平均リト ライ回数を求める必要がある. 今回の評価点は, 布量当たり 16 点とし, 合計 80 点である. この評価点を実験結 果で描くためには，条件あたりの検討時間を約 1 日とすると，約 80 日が必要となる．これだけの時間を短い開 発期間の中で確保するのは困難である. 一方, 開発した脱水起動シミュレータは, 80 点の平均リトライ回数を 1 日以内で求めることができた。 このように, 開発した脱水起動シミュレータは, 実験よりも短い時間で平均リト ライ回数を算出できる.

また，上記の関係を用いることで，脱水起動シミュレータでは閾值の調整を効率的に行うことが出来る．例え ば, 外槽の振動変位が 2 倍に増加した場合, 脱水時の振動レベルを維持するためには, 閾値を 0.5 倍にする必要 がある.このとき, 無次元化した閾值 1 に対する平均リトライ回数の増加量は, 図 11 より 3〜6 倍となる（実機 では, 図 3(B)共振通過区間におけるリトライも加わるため, 平均リトライ回数の増加量はさらに大きくなる). このように, 外槽の振動変位と平均リトライ回数の増加量の関係を予め求めることで, 閾值を調整した時の影響 度が解析上で得られるため, 脱水起動検討の段階における手戻りを防止することが出来る.

ここで, 図 11(a)と(b)の比較より, ドラムアスペクト比 $\alpha$ にって, 無次元閾值と平均リトライ回数の関係に 大きな違いは無いことが分かる. 寸なわち，ドラムアスペクト比 $\alpha=1.3 \sim 2.0$ の範囲において，ドラムやリフタ 形状が多少変わったとしても, 今回実験で求めた確率分布 $g(x)$ は大きな影響を受けないと考えられる. したがっ て, 実験で求めた衣類の確率分布 $g(x)$ を他機種に転用することで, 実機の無い設計初期段階において防振支持構 造と平均リトライ回数を同時に検討することが出来る. なお，ドラムの回転パターンを変更する場合は，衣類の 挙動に与える影響が大きいため, 確率分布 $g(x)$ の転用には注意が必要である.

以上より, 本予測方法は, ドラムアスペクト比 $\alpha=1.3 \sim 2.0$ の範囲において, 平均リトライ回数を実験よりも 短時間で評価でき，また実機のない設計初期段階でも予測可能であることから，その有用性は高いと考えられ る. 加えて, 本予測方法はモンテカルロ法を用いているため, より複雑な脱水起動制御や試行回数ごとの詳細な 予測に対しても適用可能と考えられる.

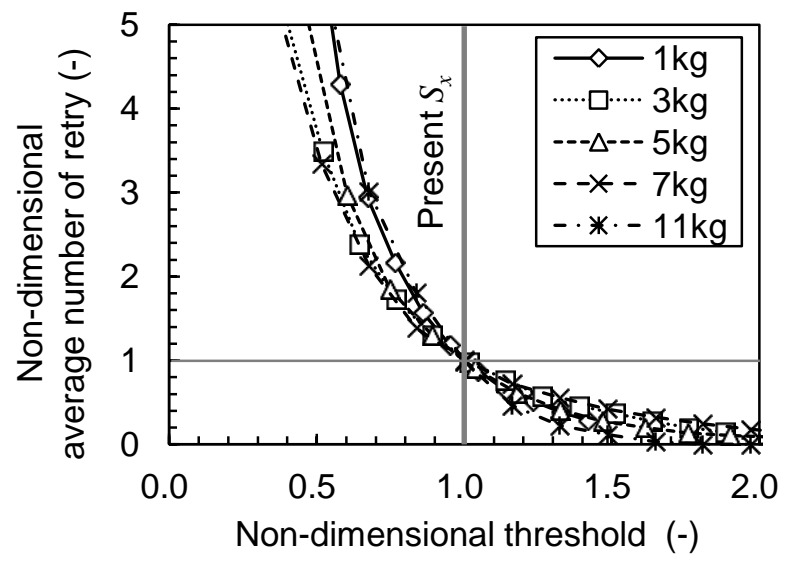

(a) Drum aspect ratio $\alpha=2.0$

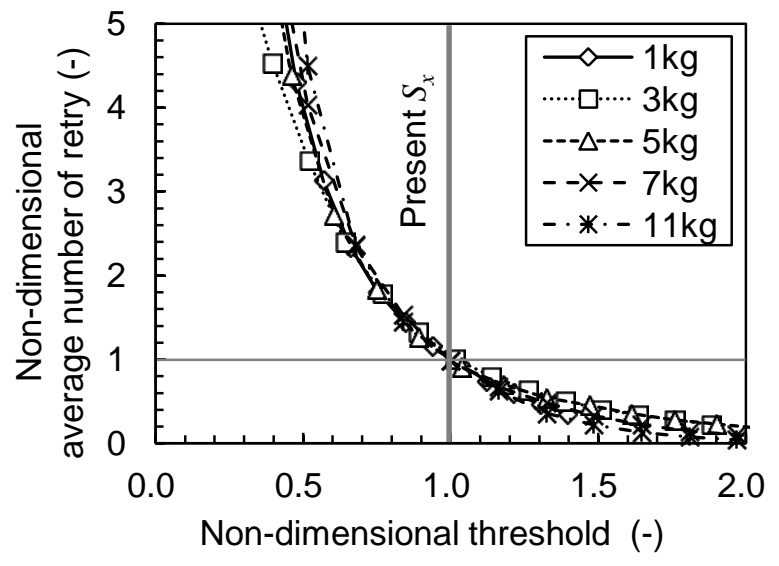

(b) Drum aspect ratio $\alpha=1.3$

Fig. 11 Relationship between the average number of retry and non-dimensional threshold 


\section{5. 結 言}

ドラム式洗濯乾燥機の低振動化を目的として，設計初期段階でリトライ回数を予測するために，モンテカルロ 法を用いた脱水起動シミュレータの開発を行った. 脱水起動シミュレータは, 衣類の挙動で変化する外槽の振動 レベルの確率分布に着目し，実験で得た振動レベルの確率分布に従う乱数を発生させ，その乱数が閾値よりも大 きくなる回数を求めることで，リトライ回数の予測を行うものである. 本研究では, 本予測方法の有用性を確認 するために, ドラム径を奥行きで除したドラムアスペクト比 $\alpha=2.0$ と 1.3 の機体に対して, 実際の脱水動作で得 られた振動レベルとリトライ回数との比較を行い, 以下の結論を得た.

(1) 平均リトライ回数は, 予測值と実験值の差がドラムアスペクト比 $\alpha=1.3$ の機体で最大 1.6 回となったが, $\alpha=2.0$ の機体では最大で 0.8 回となり, 良好に一致した.

(2) リトライによるアンバランス修正後の振動レベルの平均值は, 布量全体で平均した予測值と実験值の相対誤 差が， ドラムアスペクト比 $\alpha=1.3$ の機体で $13.9 \% ， \alpha=2.0$ の機体で $6.2 \%$ となった.

(3) 80 条件の平均リトライ回数の算出に必要な時間は, 実験で約 80 日見込まれるのに対して, 本予測方法は 1 日以内となった.

(4) 衣類の挙動で変化する外槽の振動レベルの確率分布を予め求めておけば, ドラムアスペクト比 $\alpha=1.3 \sim 2.0$ の 範囲において，実機のない設計初期段階でも予測可能であることから，提案手法の製品設計での有用性は高 い.

\section{文献}

上甲康之, 黒澤真理, 会田修司, 高橋幸太郎，ドラム式洗濯乾燥機における防振構造の多目的最適化，日本機械学 会論文集, Vol.82, No.837 (2016), DOI:10.1299／transjsme. 15-00609.

紀之内隆生, 山本宏, 稲瀬朋之, 中川克人, 前川正弘, 業務用洗濯機の振動シミュレーションモデルの開発，日本 機械学会 Dynamics \& Design Conference 論文集(2000), p.181.

松井康博, 井田道秋, 金子哲憲, 上野真司, 戸川竜太, 黒澤真理, ドラム式洗濯乾燥機の低振動化技術, IIP2008 情 報・知能・精密機器部門講演会論文集(2008), pp.210-215.

樋田勉, ハンパラメトリック・カーネル推定におけるバンド幅選択法, 早稲田経済学研究, Vol.46(1998), pp. 173183.

辻内伸好, 小泉孝之, 松本修一, 山岡直人, 脱水運転時におけるドラム式洗濯機の振動解析及び低振動化に関する 研究，日本機械学会 Dynamics \& Design Conference 論文集(2006), pp.224-226.

\section{References}

Joko, Y., Kurosawa, M., Aita, S. and Takahashi, K., Multi-objective optimum design of vibration isolation structure for frontloading washer-dryer, Transactions of the JSME (in Japanese), Vol.82, No. 832 (2016), DOI:10.1299/transjsme. 1500609.

Kinouchi, T., Yamamoto, H., Inase, T., Nakagawa, K. and Maekawa, M., Vibration simulation model for commercial laundry, Proceedings of Dynamics \& Design Conference (2000), p.181 (in Japanese).

Matsui, Y., Ida, M., Kaneko, T., Ueno, S., Togawa, R. and Kurosawa, M., Low-vibration technology for drum-type washer dryer, IIP(2008), pp.210-215 (in Japanese).

Toida, T., Methods of bandwidth selection for nonparametric kernel density estimation, Waseda Economic Studies, Vol.46(1998), pp.173-183 (in Japanese).

Tsujiuchi, N., Koizumi, T., Matsumoto, S. and Yamaoka, N., Vibration analysis and reduction of a drum type washing machine in the spin-drying stage, Proceedings of Dynamics \& Design Conference (2006), pp.224-226 (in Japanese). 